\title{
SLUM, SQUATTER, AND QUASI-SQUATTER HOUSING DEPRAVITY IN YOGYAKARTA
}

\author{
Arap Matinguny Adris \\ Graduate School Universitas Gadjah Mada \\ Suratman Worosuprojo \\ Faculty of Geography Universitas Gadjah Mada \\ M. Baiquni \\ Faculty of GeographyUniversitas Gadjah Mada \\ Email: baiquni99@yahoo.com
}

\begin{abstract}
Studi ini bertujuan memperdalam pemahaman tentang permukiman kumuh,liar,dan kuasi-liar di perkotaan Yogyakarta. Secara khusus mengkaji hubungan antara faktor-faktor penduduk dan proses perbaikan permukiman oleh warga sendiri. Pemukiman semacam ini sangat dipengaruhi oleh pendapatan rumah tangga,beban ketergantungan,dan status kepemilikan tanah.

Studi ini juga mencoba merumuskan model Client-Oriented untuk penanganan dan meneliti teori dasar penyediaan rumah tinggal oleh warga secara mandiri. Studi ini menemukan teori sebagaimana diusulkan J.Turner dan kawan tidak berdasarkan teori tertentu atau filsafat.Dengan ini studi mengajukan filsafat Etika Kepedulian dan Prinsip Covering Law sebagai titik berangkat perumusan kebijakan tentang perumahan ini oleh masyarakat. Model ini merupakan alat untuk penentuan tingkat perumahan dan ketersediaan fasilitas di permukiman.
\end{abstract}

Kata Kunci: Pemukiman kumuh, Liar, Kuasi-liar, Client-Oriented model.

\begin{abstract}
This studyaims at deepen our understanding of the slum-squatter housing issue in relation to the differences in household socio-economic factors. The theoretical basis of the study comes from literature on self-help housing,consolidation, and marginality especially by J. Turner and colleagues. Three household factors are key to the processes of taudification and consolidation in this city namely, income, dependency burden, and land tenureship.

This studyattempts to synthesise a facility allocation model i.e. a Client-Oriented model; and to establish the theoretical background of the concept of Self-Help housing advocated by Turner and friends. The study finds out that self-help housing as proposed by these researchers lacks a theoretical and philosophical setting. In this context, the study advances the Self-Care Ethic philosophy and a Covering Law theory as the departure of self-help and housing consolidation policies in urban settlements. With this in mind, the Client-Oriented model is instrumental because its purpose is to determine the degree of housing and facility in a settlement.
\end{abstract}

Keywords:Slum, Squatter, Quasi-Squatter, Self-Help Housing, Client-Oriented Model. 


\section{INTRODUCTION}

Urbanization has been rapid in the Republic of Indonesia and squatter settlements thus, proliferating amidst the aging established legal slums. Typical public reaction to squatter phenomenon has been largely negative. But to some extent, the reaction has been positive especially in the cities with greater traditional ties such as Surakarta and Yogyakarta. Indonesia's urban population living in low quality housinghave utilized quasi- and extra-legal adaptations to appropriate land for housing. In within this, housing consolidation process occurs, as a resultant of 'Expectative Property Rights', (de Soto, 1983; Garr J.D., 1996). In Indonesia where the police even eschew overt conflict wherever possible, the expectative property rights manifests itself when a squatter housing is not undisturbed (Ginness, 1986). This study thus investigated situations triggering off a greater degree of housing consolidation than have legal land tenure arrangements in Indonesian cities. There are three forms of tenure rights in Yogyakarta slum area. The first form of tenure system is of those possessing a lease of an unknown length on the land question, and hence is owned by the sultanates and its royal court, the Kraton. This group of individuals mainly in Blimbingsari, have the right to use but not ownership and so popularly known as Magarsari. Squatting on this land is similar to doing so on government owned land. The second system is that of individuals occupying state land such as along R. Code valleys, besides railway tracts and known as Wedikengser and form genuine squatters. The third system is that of genuine landowners with full rights over the land mainly in Sendowo, and the right to confer to friends and relatives thus, Hakmilik. This process of conferring thus leads to a fourth system of tenureship i.e. quasi-squatters or Ngindung. This multi-tenurial system is a component of Adat, Indonesia's unwritten, dynamic, and localised system of law.

The study at the outset addresses two aspects vital in the distribution and allocation of housing. First, the slum-squatter dilemma must be considered from a geographical perspective for many reasons in terms of; jurisdictional partitioning and tapering summed up by Lasswell's (1958) famous aphorism 'who gets what?' In the spatial context, this involves asking the question 'who gets what where?', (Smith, 1977). The second perspective derives from the need to account for this differentiation and the immediate question is explanatory i.e. 'Who gets What Where Why and How?' Within these perspectives, the immediate issue of concern is: How marginal are slum and squatter households in Yogyakarta city? Do they show any significant differences at all in the process of housing consolidation?"

\section{Grounded Theory and Covering Law Theory Developed}

The model put forward here is the ' $\mathrm{Cli}$ ent-Oriented model' to urban housing and facility allocation. To attain this objective, the study advances the Covering Law Thesis to the process of urban settlement planning and through a grounded theoryperspective, it attempts to show how the covering law and care ethic principles can be attained. The study begins with a perception of gaps in knowledge; and then focuses on three issues: (a)why do some slum - squatter residents not consolidate? (b) what is the effectiveness of the government architect-designed housing programmes (RSS and $R S n)$ in alleviating housing depravity problem? (c)what is the effectiveness of self-help housing motorised by Kampung Improvement Program (KIP) to alleviate this housing marginality or depravity issue?

A theory can refer to wide philosophical perspectives and in 1989, Jahoda distinguished theories intodown-to-earth explanations, and high-level abstractions. Empirical studies tend to produce down-to-earth theories but describe the results as high-level abstractions. Down-to-earth explanations specify particular groups or situations and encompass deviants for instance, a study such as on slum-squatter settlements. High- 
level abstractions in contrast, aim to be comprehensive and thus generalise situations but usually ignore deviants. Another clarification is by Merton (1957) who distinguishes between a Grand theory, Middle-Range theory, and Minor working hypotheses.

Thus at this stage, the question is how does our experience of the Covering Law theory and Client-Oriented model (COM) advanced here fit with Jahoda's and Merton's distinctions? The study at hand generally not only seeks to produce explanations of housing depravity occurrences from empirical investigations in Yogyakarta but also develop more abstract observations from accumulated knowledge on slum-squatter settlement management propelled by the philosophies of sustainability and Self - Care Ethic.

In as far as the Covering Law theory forwarded here is concerned, it is a middle-range theory because it links concepts such as land tenure, income, dependency burden, etc. derived from earlier results elsewhere. With this background, we suggest the Client-oriented model to urban housing and facility allocation can be applied to part of society in need and thus developing further original theories or approaches. The argument forwarded here is a reaction against the aberration theory adopted for quite long, expressed through three various views on slums i.e.: slum-squatter inability, unabsorbed immigrants, centres of political unrest.

A truly scientific approach to settlement would seek a theory which, when interpreted, can predict the observable settlement patterns in all past, present and future human habitats. Basing on available literature, one may wonder whether Turner's 'housing as a process' is indeed philosophically founded. It is a form of theologicalphilosophy, due to its role alienation hence not deeply founded. However, from an ecological viewpoint, we view it as a systems philosophy with a strong organismic emphasis that stresses the interrelationships between subsystems. Humanbeings interact among themselves, and the interactional patterns can be described as systems; people also interact with 'environmental matrices', and these interactions within the groups of organisms and between it (shelter) and the milieu, can also be considered as a system-Ecosystem.

Hence housing consolidation ethic identifies the logic of domination as the perpetuator of the oppression upon of the urban poor and their settlements. The study thus identifies housing consolidation or improvement process as an ethic that should form the basis of policies on low-income housing development. This is because in this process is bound the Care Ethic Philosophy.

\section{Care Ethic Philosophy}

This study observes thatin Turner's theory of housing consolidation, there are two vital aspects: (1) poor man's experiences must be taken seriously and (2) these experiences must be central to developing slum-squatter housing consolidation theory. In respect to this goal, the study develops an ethical system based on the values generally associated and expressed by the poor in their settlements. This kind of housing consolidation theory is the "Care Ethic".

Housing consolidation process in Yogyakarta city exhibits a model of moral development or responsibility similar to that attributed by Turner to Latin American slumsquatter settlements. This shows how an ethic of care originates in slum - squatter settlements. However, what we ought to observe is the fact that our pain for the death of the urban environment is fundamentally, compassion for the senseless destruction of life. The compassion felt is the essence of a new paradigm. This study names it the paradigm of feeling the life of the "other". The idea that the poor should claim aspects of themselves that have been disvalued by the elitist and proletariat culture could be ethically vital. Reclamation of historically developed ways of life might serve as the basis for an ethic that subverts oppressive values and represents 
alternative paradigms. For example as per the results of two pilot studies in Surakarta (ArapMatinguny, 1996; 2004 and Yogyakarta 2005), we find that important insights into the values of bonds of affection and virtues of friendship (expressed as 'Gotong-Royong') are gotten through the analysis and experience of friendship between the poor and the non-poor.

The concept of care ethic is rooted in the principle that "people are far better-off when they are free to make their own contributionsin the design, construction, or management of their housing. As such, in order to achieve a viable care ethic housing policy, the study advances three proscriptive principles that are worthy of noting: (i). necessity of selfgovernment in local affairs for which the principle of local and personal freedom to build must be kept; (ii). necessity for using the least vital power, weight, and size of tools for the job, and (iii). planning is an essentially legislative, limit-setting function and so must cease to be confused with design that deals with laying down lines of action.

Turner (1976) makes an outcry that "No generally known and recent thesis deals with this vital principle of proscriptive law in housing and environmental planning". As such, Turner called for an effort into thought, research, action and development. To initiate these activities, he advanced four proposals that need attention:(a) setting up an international communications network to intensify usage of existing channels of communication so as to increase universal access and reduce the risks of exploitation; (b) setting up a number of interconnected centres for case mate- rials collection and availed to those needing precedents set; (c) instituting a new school of the built environment; and(d) initiating a program to design a proscriptive law to enable a self-governing form.

This is because for all developing countries, housing policies have been based on wrongly stated problems. There is no greater evil than a problem missstated. No policy can be well formulatedwithout comprehension of underlying issues. Ecologically, housing is a subsystem of the general system and so any subject matter of value must have three elements: people, the things they do, and the relationships between the two. Thus building as per Bertalanffy's (1948) general systems model, a slum-squatter settlement can be expressed as in the following Figure 1 below.

Organism $\rightarrow$ Function $\rightarrow$ Environment

Figure 1. Bertalanffy's Model Recognises These Relationships as Feedbacks and Feed-Forwards.

Hence organisms (man) and environment (settlement) through functions interact as can be expressed in housing consolidation. Housing consolidation is the interaction of the people (organisms) and their products (builtenvironment) through the medium of their roles and responsibilities (ethics). However, in this study, these are translated as organisms (carers), past experience (feedbacks) and future expectations (feed-forwards). Perceived as such, the model can be modified as Figure 2 below:

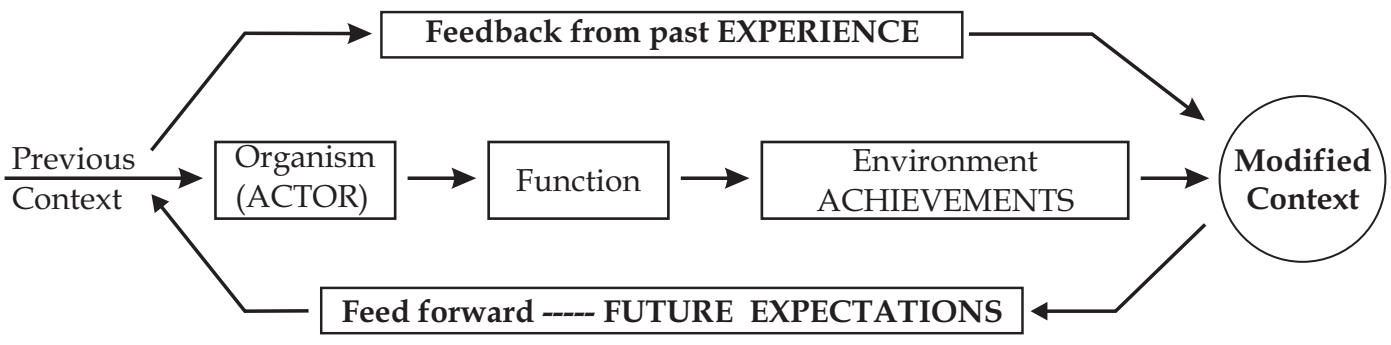

Figure 2. Bertalaffy's Simplyfied Model for Housing Process 
From Figure1 above, Bertalanffy's model observes that there are three elements: Organism, Function and Environment. Modifying this model in 1948, he shows that there are three elements viz: the pre-existentcontext, the subsequently modified context, and the direct relationships (feed-backs and forwards) which by-pass the particular process. What these relationships, organisms, functions, and environment in this model means, is not clearly stated, and hence it is not a surprise that policies based on such a model are destructive because the housing problem is not correctly stated.

The task of this study is to emphasise their interdependence; and to identify the critical model or theory linking all the tasks involved in the housing process. For long, it has been difficult to know the laws governing the use and management of space, and the social as well as the economic nature of its provisions. Thus, the basic argument advanced here is that: Without a thorough understanding of accurate and complete theoretical models of the built-environment, no correct law for any housing process or system can be written. Therefore, in line with Turner's outcry for a new thesis and theoretical model, Bertalanffy's model has to be revised. In the revised model as figure 2 above, it is realised that at any level of organisation i.e. either personal, group or government, actions generate and are generated by the experience of past actions, administration, information, or norms (bulk of housing laws).

The primary research goal isto identify factors within slum-quasi-squatter households that affect housing consolidation(selfhelp housing) and marginality processes through studying the values, attitudes, and behaviours of households. Stated simply as to:(a) describe levels of marginality amongst slum - squatter households; (b)inquire into the means by which they have managed to cope up with it, and(c)develop some theoretical model that may be useful to urban facility allocation planning.

\section{Research Method and Design}

The idea of synthesis adopted here is cause - effect approach. The cause - effect analysis is a scientific method based on the view that the past can explain the present. In this study, we look for causal relationships by comparing data on housing depravity in Sendowo-Blimbingsari study area in Yogyakarta. Close examination of, "who" is deprived of "what" and "where" is vital for it can reveal its causes, extent and the trend "why".

By following the same households to this time, the main objective is to provide a longitudinal data set for housing improvement. The study generally collected continuous data on the physical conditions of housing histories covering any improvements within the period 2007-2012. Other areas of the schedule such as looking into the degree of marginality or depravity, however, was limited to collecting information on the respondents' current situation at the point of study. What is clear is that the quantitative data sets not only allow housing consolidation and marginality to be analysed but also a sequence of observed outcomes measured at periodical basis. Finally, the policy dilemma discussed at the conclusion is: "If we are to target housing assistance to the worst-case needs, should we plan along the dualistic connotations of formal - informal, legal - illegal, or slum - squatter again if the rift is narrowing?"

These are the policy issues that will help shape out the focus on the findings in this study. However, for purposes of clarity, the study adheres to the latter perspective of housing as a process leading us to housing consolidation process. Slum - squatter communities are deprived of what they need for livelihood but they see it with others in the same environment. Knowledge about the marginalised man and slum-squatter settlements is essential for adopting sound development strategies and effective policies against marginality and taudification. Taudification is the process by which slums form. 
How many marginal households are there? Where do they live? Under what circumstances are they precisely living?

Answering these questions is the first step toward understanding the impact of governmental policies on marginality and hence growth of slum- squatter settlements. These three types of families-slum, quasi-squatter, and squatter households - in Yogyakarta city are alike and so, lifting them out of marginality and taudification will depend largely on a better understanding about them.

The study also gets involved in developing an instrument to measure residential consolidationby designing two independent tools - Housing Consolidation and Material consolidation indices - which when put together form a global consolidation index. These tools are attained definition of one or more indicators for each sub-component, and assigning weights and values for each indicator and its categories. The values of the subcomponents in the following ranges:

0-13 (too temporal and excellently permanent respectively); and

14-18 (availability of basic facilities water and sanitation).

19-31 (permanent housing with sophisticated facilities)

To answer adequately the policy question for which the study has been designed - What makes for the effective implementation of a self-help housing or consolidation policy?both qualitative and quantitative methods of analysis have to be used in an integrated manner. To analyse residential segregation, three techniques: the Index of Dissimilarity (ID); the Index of Segregation (IS); and the Location Quotient $(L Q)$ were employed.

\section{RESULTS AND DISCUSSION Philosophy of Self-Care Ethic and Self-Help Housing}

What is meant by "Self", Ethics Care and their relation to housing? In a wider context, this philosophy of Self-Ethics Care advanced here is a combination of two philosophies i.e. 'Self' and 'Ethics Care' as can be explained below:

\section{(a) Philosophy of 'Self'}

"Self" in relation to an individual until today, man finds hard to identify himself just as he finds hard to identify others. We try to answer at times because we want to know, but at times for practical reasons. Who am I?, Who are you? We at times point to ourselves: "I think", "I must", "I hope". Are we at that very moment at the level of consciousness? Or when the authorities talk of community houses (perumahanrakyat), are they conscious of the community? So if not, how can we be conscious of ourselves? Just as much has been said about the nature of man and whether he has an essence, we must also investigate the nature of "self" and its essence to the process of housing and facility allocation.

Even though we cannot provide a perfect definition, it is a vital concept of life. We cannot disregard "awareness", "self-consciousness" and "mind" from our interpretations about human issues without disregarding central issues in human experience.There are many aspects of "self" which must be understood before we can talk of "Self-Help" and Housing. Self must be viewed as: the centre of Individuality (self-hood); a Controller; something private; and a subject.

\section{(b) Ethics Care Philosophy}

Ethics means customs, culture or habits and as such, it implies habits of livelihood said well to an individual or to the whole community as a whole. These good habits of livelihood are adored by the whole society in question and are passed from generation to generation. These are locally local principles, laws or norms informally taught to the young generation. In short, these determine what can be said good or bad habits and the consequence of violation is a natural cuss by the ancestors (hukum karma). 
Thus, ethics is the content of informal education about how an individual is supposed to lead a normal life as a humanbeing. Irrespective of their differences, all ethics and morals have one thing in common i.e. they are intended for either the betterment or worthiness of humankind as a human being and his harmony with the entire environment.

At this point, ethics calls for a critical evaluation of all aspects related to merits and demerits as a whole. Thus issues such as who is affected; what is affected; and what is the loss?,etc. are the foci. Therefore, Care ethic philosophy as advanced here needs help from other disciplines to arrive at a valuable moral decision or recommendation, and hence can be considered an interdisciplinary philosophy. This is a concrete situation because it argues for the two perspectives of ethics and morality.Firstly, 'act as per the norms and principles available that are noted satisfactory. Secondly, undertake a critical reflection to make a right decision as per your own conception (self A)'. This means administratorsmust be open-minded. Thus as a leader, the first question is 'who am I (Self A)?'

\section{(c) Self - Care Ethic Philosophy}

Basing on these two differences, the SelfCare Ethic philosophy is philosophy according to the second perspective: a critical reflection about the norms and values or moral principles adored by the community all long in relation to the living environment; and a critical reflection of the ways man (self $A$ ) perceives man (self $B$ ), nature and settlement (It). From this critical reflection, a proper way of perception, decisions, and actions considered right especially in the framework of rescuing housing and environmental crises may be formulated. Therefore, the SelfCare Ethic philosophy is grounded on the critical reflection. This perspective provides three different approaches namely deontology, teleology, and prioritisation.

Firstly approach deontology as far as the question above is concerned, will answer 'do what becomes your obligation or responsibility as provided by norms and values available'. Here deontology is not concerned with the impacts of the action at all. But according to self-care ethic perspective, demolition will be evaluated immoral because of its negative impacts. Hence, in a situation of slum-squatter settlements, deontology cannot provide an answer that respects the laws of moral universality.

Secondly, approach of Teleology stresses the importance of the goal or the impact of an action to be taken, i.e. choose an action that brings with it morally good results, and so it means an action like demolition is not morally good because it brings with it loss. Thus, teleological ethics also does not provide a satisfactory answer.

Thirdly, approach is Virtue Ethics or prioritisationstresses the development of a moral character within every individual of society. This perspective is in line with that of the great philosopher Aristotle who argues that moral values are founded and derived from one's experiences in the community, from the ways community figures and leaders perceive and handle problems in life.

By listening first to other voices especially from the low-income communities and taking into account their contributions, experiences, and relations in the cities, the self-care ethics philosophy advances the Covering Law theory based on values of care, harmonic relationships, and trust based on the following assumptions:

(i) Man becomes or realises the 'self' anywhere whenever he is involved in an inter-subject relationship,

(Self A

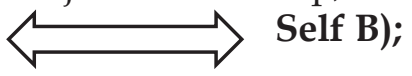

(ii) There is harmony (kesataraan) amongst all other ecological species that motives man to love, conserve, preserve and care for organisms as well as him-(self) as a member of that ecological community

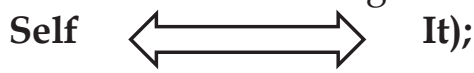

(iii) mankind has a moral obligation or responsibility to one another and to nature i.e. reverence or respect for life; and 
(iv) life, be it of mankind or other living species has some moral and ethical values i.e. it is valuable. This is the element of humanity for by humanity, man must have respect and feeling for the entire ecological system.

These assumptions can diagrammatically be shown as in below.

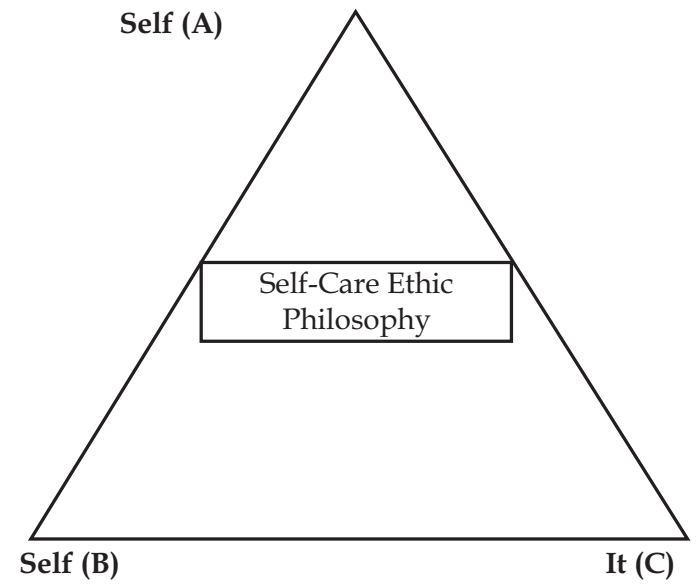

Figure 3.Graphical Representation of the SelfCare Ethics Philosophy.

Henceforth, in housing and facility provision in urban environments, the model from this self-care ethic philosophy with the principle of virtue or respect for life is housing consolidation process through self-help (gotong-royong). Through self-care ethic philosophy, slum-squatter household heads try to show the value in their helpless family members. The responsibility, obligation and love expressed by this self-help housing consolidation arise as an ethical norm and principle colouring a unique relationship amongst the residents.

\section{RESEARCH FINDINGS}

Sendowo-Blimbingsaristudy area displays varying physical, demographic, and socioeconomic features. Some of the neighbourhoods here are genuine slum settlements (Sendowo), whereas others are squatter areas where families have relocated themselves on sultanate and publicly owned land (Blimb- ingsari). However, within these neighbourhoods, quasi-squatters are found too wherein through infilling process, families have occupied privately held-parcels of land on either social relationship or rental terms. Differences in land tenure legalitydefinitely affect the process consolidation. Thence in this study, three types of communities can be identified i.e. slums, quasi-squatters, and squatters basing on the legality of the lot occupied. In all, the distribution of these settlement typologies can be seen in the concentration of communities according to their socio-economic characteristics (marginality levels) and the location quotients of urban facility needs as shown in the following Table 1.

As argued by many scholars (Turner et al. 1969), the security of tenure is vital in the process of housing consolidation. This study shows that land tenure is not the utmost factor. There are other factors with an equal influence such as income, age of the household head, dependency burden, and educational levels attained by household heads. Factors like duration of stay, population nativity, additional income, job type, and adult population size although having large correlation values with consolidation, their level of significance is intolerable even at a $0.25 \%$ or $0.75 \%$ confidence level.

As such, it was established that most important factors are income (inc.), number of children in a household $\left(X_{\mathrm{I}}\right)$, age of household head (a), level of education attained (ed), job type (jb), population nativity (pn), and land tenure status (TS1). The regression programme generated a correlation matrix and the following model1 (m1):

$0.46_{\text {inc. }}+0.20_{\text {ed }}-0.28_{\mathrm{XI}}-0.14_{\mathrm{a}}-0.57_{\mathrm{TS} 1}-0.07_{\mathrm{jb}}-0.08_{\mathrm{pn}}(\mathrm{m} 1)$

(.000) (.090) (.031) (.117) (.000) (.095) (.237)

(values in the parentheses are $\mathrm{T}$ Test significance levels).

All variables in this model showed a multiple correlation coefficient (R) of 
0.96740, and the coefficient of determination $\left(\mathbf{R}^{2}\right)$ of $\mathbf{0 . 9 2 7 2 9}$, thus explaining $94 \%$ of the heterogeneity in housing consolidation in this area.Factorssuch as household income (.46), land tenure (.57), and the number of children in a household (.28) are statistically significant at 0.05 confidence level.

Table 1: Research Results on Location Quotients in Sendowo-Blimbingsari

\begin{tabular}{l|l|l|l}
\hline \multirow{2}{*}{$\begin{array}{c}\text { Household } \\
\text { Characteristics }\end{array}$} & \multicolumn{3}{|c}{$\begin{array}{c}\text { Sendowo_Blimbingsari } \\
\text { (Household Type) }\end{array}$} \\
\cline { 2 - 4 } & $\begin{array}{c}\text { Slum } \\
\text { (LQ) }\end{array}$ & $\begin{array}{c}\text { Q.Squatter } \\
\text { (LQ) }\end{array}$ & $\begin{array}{c}\text { Squatter } \\
\text { (LQ) }\end{array}$ \\
\hline Chn (mean) & 1.71 & 1.70 & 1.72 \\
\hline Age <30>60 & $18.2 \%$ & $17.8 \%$ & $25.6 \%$ \\
\hline Inc.<Rp.400 & $90.8 \%$ & $96.8 \%$ & $100 \%$ \\
\hline Educ.(0-6) \% & 56.9 & 57.1 & 78.9 \\
\hline Land Tenure & $47 \%$ & $22 \%$ & $31 \%$ \\
\hline & & & \\
\hline Facilities & & & 6.1 \\
\hline Water \% & 3.1 & 5.3 & 68.4 \\
\hline mck (3-4) \% & 32.8 & 46.4 & 93.1 \\
\hline HQI \% & 46.1 & 67.7 & 48.41 \\
\hline Lot (hm) $\mathrm{m}^{2}$ & 62.1 & 40.32 & 43.2 \\
\hline Strct (hm) $\mathrm{m}^{2}$ & 56.9 & 33.7 & 12.4 \\
\hline Flr (hm) $\mathrm{m}^{2}$ & 16.8 & 10.6 & \\
\hline & & & 32.0 \\
\hline Consolidation & & & 17.7 \\
\hline Tmp - Sp \% & 44.0 & 24.0 & \\
\hline Sp - Pm \% & 45.0 & 22.5 & \\
\hline Facilities \% & 47.1 & 35.3 & \\
\hline
\end{tabular}

Source:Analysed Field Survey Data, Sendowo-Blimbingsari, 2007 2012.

To establish what proportion of the variance these three factors account, a stepwise regression analysis was constructed. This method selects the independent variables with the highest coefficient of determination for the dependent variable. This factor explains most effectively the variance of housing consolidation score. Having incorporated all the factors, - income (inc.), land tenure status (TS1) and the number of children (X1) were selected as the most important factors and the following model2 $(\mathrm{m} 2)$ was elicited:
$\mathrm{HQI}=-0.49_{\text {inc }}-0.59_{\mathrm{TS} 1}-0.25_{\mathrm{x} 1}(\mathrm{~m} 2)$

(.00) (.00) (.029)

These factors produced a correlation coefficient (R) of 0.786 and coefficient of determination $\left(R^{2}\right) \quad 0.58$ and therefore, it implies that they account for $58 \%$ of the total variance in housing. Thus in SendowoBlimbingsari, the most important factor is land tenure status with a negative correlation factor of -0.59 then followed by income -0.49 .

\section{The Provision of Basic Housing and Related Facilities}

The action of welfare planning and other services include diverse entities such as shelter, water and sanitary amenities amongst others. Irrespective of their variedness', they all involve contact between the authorities and the needy. Accordingly, the identification of the needy sections of the community may bear directly on the success and survival of a given programme and so the locational question: "Who needs, what and Where?" is of utmost vitality.

This study having analysed existing housing conditions in Sendowo-Blimbingsari, proposes a three-step strategy for providing housing and associated facilities. Due to the budgetary, labour, and other resource constraints restricting the amount of services tobe provided to the entire low-income needy population, particular attention is given to applying the Target Identification Strate$g y$. At the minimum, this strategy is expected to serve as a guide for designing alternative strategies, and a baseline for gauging their effectiveness. Thesesteps are as follows as established by the study:

(a) Establishing the characteristics by which the targeted households are to be identified:

It is important to establish the characteristic that will determine the target population. The target population consists of households with: higher dependency ratios; low 
incomes below the general median income of this group (Rp250.000,00) per-month; low levels of education or illiterate; household heads engaged in informal manual occupations; elderly headed households or recent immigrants; and thelandless, i.e. quasi-squatters and squatters.

\section{(b) Determining the Spatial Distribution of Housing and Facility Needs}

Funds for population service systems are allocated for areas but these areas are large jurisdictionally to serve as meaningful targets for locating individual family facilities. Units are needed with areal extents and target populations that do not exceed the service capacity of the facility, unlike the situations in RWs 42 and 56. In RWs 42 and 56 , one standing water pipe serves over 65 households. Large numbers of households to be served by a facility, also constraints the organisation of the facility's upkeep.

This study accomplished it by deriving a regression equation employing socio-economic variables tabulated at the survey tract level. We substitute the same variables into the equation as a weighting variable to estimate the number of households in need of housing facilities at the RT/RW areal block units. The resulting model (m1), estimated by stepwise regression procedures, explains $89 \%$ the variance in the housing marginality problem or needing facilities across the survey tracts;

$$
Z_{i}=0.55_{w}+0.214_{t}+0.89_{h}-0.66_{a}
$$

where, $\boldsymbol{w}$-water, $\boldsymbol{t}$ - toilets, $\boldsymbol{h}$ - housing, and $\boldsymbol{a}$ - needing all three facilities.

However to establish the magnitude of household characteristics on the model, the model equation was run first without consid- ering these factors. Thence weighting household needs by these factors, the following equation (model 2) was obtained:

$$
Z_{i}=0.32_{w}+0.16_{t}+0.77_{h}-0.60_{a}
$$

While the unweighed model equation (m1) has a correlation coefficient of 0.92 and a correlation determination $\left(\mathrm{R}^{2}\right)$ of 0.86 , we find that this model under-predicts the needy households when predicted results are compared with the reality as indicated in Table 2 below.

But when this model is weighted (m2) by household characteristics, the realised results tend to match with reality. For example in this area, the total predicted number of the needy households is $Z_{\mathrm{i}}=85.88$, with water $=$ 21.75; toilets 20.841; houses 38.87; and all 3.88 as clearly shown in Table 3 below. This fact is supported by the change in the coefficients of correlation and determination $\left(\mathrm{R}^{2}\right)$ that rise to 0.956 and 0.913 respectively; as well as the standard error that drops from 0.453 in the unweighted model (m1) to 0.23 in the weighed model (m2).

Table 2: Comparison between Predicted results and the Reality

\begin{tabular}{l|l|l}
\hline \multirow{2}{*}{ Facilities needed } & \multicolumn{2}{|c}{ Sendowo-Blimbingsari } \\
\cline { 2 - 3 } & Reality & Predicted \\
\hline Water $(\mathrm{w})$ & 24 & 21 \\
\hline Toilet $(\mathrm{t})$ & 22 & 19 \\
\hline Housing $(\mathrm{h})$ & 41 & 33 \\
\hline All $(\mathrm{a})$ & 4 & 2 \\
\hline Total & 91 & 75 \\
\hline
\end{tabular}

Source: Processed and analysed Field Data, 2007 - 2012.

Once $Z_{i}$, a percentage figure is calculated for each areal unit, it is multiplied by both the number of families in the jurisdictional block (RT) and the average number of children below 15 years of age per household to estimate the actual number of the needy people as spatially presented below (Table 3). 
Table 3: Spatial Distribution of predicted needy population inSendowo-Blimbingsari.

\begin{tabular}{|c|c|c|c|c|c|c|c|c|}
\hline \multirow{2}{*}{ RW } & \multicolumn{2}{|c|}{ Needy HHs } & \multicolumn{2}{|c|}{ Children } & \multicolumn{2}{|c|}{ Adults } & \multicolumn{2}{|c|}{ Total } \\
\hline & No & $\%$ & No & $\%$ & No & $\%$ & No & $\%$ \\
\hline 67 & 2218.2 & & 34 & 13.2 & 7819.6 & & 112 & 17.5 \\
\hline 64 & 2218.2 & & 26 & 15.0 & 9223.1 & & 118 & 20.6 \\
\hline 42 & 2823.1 & & 47 & 22.2 & 8621.6 & & 133 & 21.8 \\
\hline 38 & 2016.5 & & 35 & 19.3 & 5112.8 & & 86 & 14.5 \\
\hline 56 & 2924.0 & & 51 & 30.5 & 9122.9 & & 142 & 25.6 \\
\hline Tot. \% & 121 & 87.05 & 19332.7 & & 39867.3 & & 591 & 100 \\
\hline
\end{tabular}

Source: Processed analysed Field Data, 2007- 2012.

A high concentration of housing needoccurs throughout the jurisdictional units, with exception of those areas RWs 67, 64 and 38 i.e. $18.2 \%$ and $16.5 \%$ respectively. This may be attributed to the fact that in Yogyakarta city, residents of these jurisdictions have well-defined tenure rights.

\section{(c) Definingwhichtarget areal units.}

The result of step 2 is a map portraying the spatial distribution of the need for either facility. This indicates several neighbourhoods that are possible candidates for receiving extensive housing assistance. Illustrating a procedure for placing centres in these areas, attention is focused upon the highest and most extensive peaks on the need services. This is accomplished via two steps i.e. location quotient and spatial population threshold results per facility.

If $n$ jurisdictional areas are established for assistance, one locational strategy is to choose the $n$ highest peaks on the surface. A set of criteria may be used to maximise the number of people served within the constraint, allowing no facility overstrained, and holding a minimum i.e. the total number of people or households served by a facility. The provisional problem then becomes one of deciding which areas best meet these criteria. This is achieved through formulating the problem as a threshold population model.

Therefore to determine the number of standpipes, vital factors influencing sustainable usability of the utilities are residual mains pressure and the number of people or households to be served. To analyse standpipes and water closet toilet facilities, the following eight steps were undertaken by establishing the:(i) average demand for water per household, i.e. 22 litre buckets (40 litres/household); (ii) time taken to fill each bucket including waiting and this was around 5 minutes in the daytime and about 3 minutes at night i.e. 4 minutes / bucket;(iii) duration of operation of the pipes i.e. $12 \mathrm{hrs} /$ day and hence $(12$ hours $)=$ 720 minutes;(iv) one tap serves $(720 \div 10)=$ 72 households or 360 people daily at constant pressure use;(v) next population of the area, i.e. on average, it is about 321.62 persons/ ha.(vi) number of standpipes needed per hectare i.e. $(321.62 \div 72)=4.47$ standpipes; (vii) distance of all households from the nearest standpipe i.e. dividing a minimum standard for location e.g. 200 metres (World Bank Standard, 1998) by the number of standpipes per hectare $(200 \div$ $4.47)=44.74$ metres of nearest standpipe; and finally,(viii) amount of population pressure exerted on the already existing facilities. It is an important variable in any planning process and was computed with the following formula:

$$
I=\frac{\mathbf{P a}-\mathbf{P t}}{\mathbf{F}}
$$

where, $I$ is the pressure index exerted on the facility $(\mathrm{F}), \mathrm{Pa}$ is the actual population being served by the facility less those with individual connections, and $\mathrm{Pt}$ is the threshold population that one facility is expected to serve in a neighbourhood (72 households). This figure gives the number of people in a locality in need of the facility. A pressure index of zero shows negative pressure with no problems and hence there is no need for an additional facility. The results of this analysis are presented as follows Table 4 below: 
Table 4: Population-Facility Pressure and extra facilities needed in Sendo-Blimbingsari

\begin{tabular}{l|l|l|l|l|l|l|l|l|l}
\hline $\begin{array}{c}\text { Area } \\
\text { RW }\end{array}$ & $\begin{array}{c}\text { No of } \\
\text { Hhs }\end{array}$ & Area Ha & $\begin{array}{c}\text { Pop. Density } \\
\text { (prsns/ha) }\end{array}$ & $\begin{array}{c}\text { Fac. } \\
\text { avail. }\end{array}$ & $\mathbf{P}_{\mathbf{a}}$ & $\mathbf{P}_{\mathbf{t}}$ & $\begin{array}{c}\text { Index } \\
\text { (I) }\end{array}$ & $\begin{array}{c}\text { Extra } \\
\text { Need }\end{array}$ & $\begin{array}{c}\text { Distance } \\
\text { (metres) }\end{array}$ \\
\hline 67 & 83 & 1.93 & 219.3 & 1 & 40 & 72 & -32.0 & 1.1 & 7.84 \\
\hline 64 & 92 & 2.34 & 212.3 & 2 & 47 & 72 & -12.5 & 0.95 & 8.70 \\
\hline 42 & 239 & 2.98 & 385.0 & 2 & 63 & 72 & 34.5 & 1.8 & 13.13 \\
\hline 38 & 306 & 3.21 & 410.0 & 3 & 158 & 72 & 28.7 & 2.2 & 36.74 \\
\hline 56 & 181 & 1.54 & 576.0 & 3 & 214 & 72 & 47.3 & 3.5 & 43.67 \\
\hline $\mathrm{Ttl}$ & 901 & 12.00 & 367.9 & 11 & 1051 & & 23.7 & 9.6 & 44.74 \\
\hline
\end{tabular}

Source: Processed analysed Field Data, 2007 - 2012.

From Table 4 above, it we see that RWs 67 and 64 have lower pressure values and so no need for additional facilities. Whereas RWs like 42 and 38 are really in dire need for more facilities. We also see that the need for more facilities is great because few households have their own direct water supply and water-closet toilet connections. This can be proved by average distance needed to reach the service i.e. 44.74 metres.

\section{Patterns of Residential Segregation amongst Slum-Squatter Households.}

The underlying framework for much of this section is the ecological model of resi- dential succession (Burgess, 1952). A major assumption of this model when applied to ghetto areas is that levels of squatter segregation will diminish over time as the squatters assimilate into mainstream urban society. Nonetheless, these overall patterns of spatial segregation vary considerably between different household subpopulations in terms of household characteristics and hence housing consolidation. Finally, results of this study reveal that quasi-squatters are the least segregated from slum dwellers; and the squatters are the greatest segregated from slum households as indicated Table 5 below.

Table 5 Indices of Spatial, Residential Segregation and Location Quotients

\begin{tabular}{|c|c|c|c|c|c|c|c|c|c|}
\hline \multirow[t]{2}{*}{ Factors } & $\operatorname{Slums}\left(X_{i}\right)$ & Q-Squt $\left(Y_{i}\right)$ & \multicolumn{7}{|c|}{ Squtrs $\left(Z_{i}\right)$} \\
\hline & $\mathrm{ID}_{X Y}$ & $\mathrm{ID}_{\mathrm{xz}}$ & $\mathrm{ID}_{Y 7}$ & $\mathrm{IS}_{X Y}$ & $\mathrm{IS}_{\mathrm{xz}}$ & $\mathrm{IS}_{Y Z}$ & Loc- & uotient & s (LQ) \\
\hline Land tenure & 52 & 68 & 64 & 24.8 & 45.1 & 47 & 2.44 & 1.12 & 4.46 \\
\hline Nativity & 5.0 & 6.0 & 5.0 & 8.5 & 13.1 & 15.0 & 1.01 & 0.99 & 0.95 \\
\hline Education & 9.1 & 31.1 & 36.3 & 28.8 & 89.7 & 62.8 & 16.74 & 16.12 & 4.6 \\
\hline Occupation & 11.5 & 30.5 & 33 & 24 & 46 & 16.5 & 9.0 & 7.35 & 37.4 \\
\hline Income & 17.2 & 19.8 & 27.3 & 53.75 & 49.5 & 47.1 & 5.31 & 1.99 & 0.77 \\
\hline
\end{tabular}

Source: Processed and analysed Field Survey Data, 2012.

An urban area is distinguished into three spatial spaces; the city of death, the city of superfluity, and in between these spaces, is the city of needs. The city of needs just as in between Yogyakarta city and Gondolayu and Jogoyudan, is an example of the city of needs. In this sense, considering only the indices of dissimilarity, we see that in Yogyakarta these indices are very low. The indices of dissimilarity recorded are such that between: slums and quasi-squatters (17.2\%); slums and squatters (19.8\%); and quasi-squatters and squatters (27.3). This implies that slum, quasi-squatter, and squatter households in this city have a more similar spatial distribution pattern than either between quasi-squatters and squatters households. This strongly supports the fact that the process of quasisquatting i.e. 'ngindung' or 'magarsari', does occur on privately held parcels that may be belonging to the already established slum or other household type. 
On the other hand, the indices of residential segregation are very low too, implying that for example in terms of income, there is vital segregation of settlements. For instance, the index of residential segregation $\left(I S_{X Y}\right)$ between slum and quasi-squatter households is $53.75 \%$; and for both slum and squatter, it is $49.5 \%$; and for quasi-squatter and squatter households it is $47.1 \%$ (Table 6) above. This implies that according to income alone, there is no meaningful spatial separation amongst the residents. Nevertheless,according to the nature of land tenureship, we see the existence of a meaningful residential segregation between the already established households i.e. the slum residents and the arrivals consisting of quasi-squatters and squatters as indicated above.

Theoretically, we advance an optimal housing consolidation model by referring to identified psychological or economic concepts so important to our analysis of human decision-making. With this, we find ourselves in the kind of theoretical structure, which explicitly includes behavioural notions. The axiomatic treatment of this slum - squatter housing consolidation problem that begins by describing the postulates and assumptions usually made with respect to the general characteristics of slum - squatter settlements.

Basedon the fact that studies on human settlements appear to have a range of phenomena that can be described and analysed with reference to a 'unity' or to a 'system', such a unity or system is not necessarily purpose-predetermined but rather individualdetermined. Therefore:

- phenomena must be understood in the light of functional associations and circular causations within the wholeness.

- culture is an indivisible wholeness from which an explanation for single occurrences such as slum-squatter settlements may be derived.

- A slum - squatter household is a functional unit - an 'organism' which is more than its parts.
- A function is an activity performed by a structure that maintains a system of which it is a part.

- $\quad$ The theme of organic analogies points to the methodological strength of functionalism lying in its support of reciprocal relationships, conditions, and feedbacks. In this sense, the study defines a function as (i)the contribution that some item makes towards the maintenance of some given subsystem,or system; and (ii)a mathematical expression between variables or as an 'indicator' of the use-value and hence the Client-Oriented model $(\mathrm{COM})$ synthesised here.

$$
\begin{aligned}
& \mathrm{HQI}=0.47_{\text {inc. }}-0.33_{\mathrm{TS} 1}-0.16_{\mathrm{x} 1}(\mathrm{~m} 2) \\
& (.00)(.00)(.029)
\end{aligned}
$$

The model consists of two definitions of $\left(X_{i}\right)$ - the set of all slum-squatter household characteristics and (HQI) - the set of all nonpositive slum-squatter physical characteristics. This model states the principle of transivity.

\section{Slum, Quasi-squatter, and Squatter Settlements are Necessary Evils}

The poor and unemployed may see the concept of welfare state as promising security or even affluence. The professional administrators and academicians usually conceive poverty as a suitable ground for potential social problems, and therefore call for an efficient instrument to control these economic and social problems. By this time, even the tax-paying man on the street and professional administrators have accepted most features of poverty as at least necessary evils. The existence of slum, quasi-squatter and squatter settlements in most urban areas are an indication of the feature of poverty in these areas and hence are necessary evils.

In this study, I should like to offer some observations on what I consider to be the logic of development of an instrument that can be applied to control these evils and hence move towards the welfare state. During my extended stay in Indonesia, I was amazed at 
the unusual mutuality of admiration between developing world (African and Asian countries) and the developed world (Europe and the U.S.). Asians and Africans are led to believe that the Europeans and the Americans are far ahead of us in almost every area of life. Academic experts in social policy studies in developing countries do agree that their countries are quite backward compared to western countries. It is true that the success in the western world is simply conditioned by the residue of the post-fascist period of "re-education" that is still very prevalent.

Of course, it is true that the proportion of people who starve or suffer from other unmet needs such as in housingcan vary considerably. But two essentials are overlooked by this kind of qualification i.e.: commitment of these nations to the goal of welfare; and the western world created endemic systems in the developing world.

\section{The Self-Care Philosophy and the Client-Oriented Model (COM)}

Self-help housing through the process of housing consolidation amongst all types of households is an expression of the settler's priority for home ownership and hence ready to settle, consolidate and improve his family's status. This process is tied to three principles of housing viz: self-government in housing; appropriate technologies for housing; and housing through limits. According to the third principle, people in their own localities have ultimate authority over housing as investment and maintenance depends on resources that only they can use economically. This principle would require central authorities to guarantee limits to private actions thereby ensuring equitable access to resources and avoiding exploitation or domination.

The Client-Oriented model (COM) realised here can serve as a method for estimating future land requirements and their probable positions within and around a city. This is useful especially from its ability to determine the number of people in need of shelter, or in need of other settlement-related facilities. Studies on human settlements especially slum-squatter settlements all along can be said to be descriptive or positive, because here theories seek to account for observed phenomena. In positive theories the observations of discrepancies between the predicted state and the actual state of settlements may stimulate an advance or changes in the theory; whereas a normative theory is used to create a world that is 'rational', and such a theory is useful for town and regional planning.

The essential characteristic of the ClientOriented Model is its normative character. The theoretical construct is not intended to show how the slum-squatter settlements are actually, but how they should be organised. This model is expected to be used as a device whose utility is measured by the success of its predictions, and not by its implicit validity or truth. The approach to its laws in this context is instrumentalism. In this sense the Client-Oriented Model will be perceived as an instrument of manipulation rather than/ or as an explanatory device.

The Client-Oriented model seeks to be a working approach to those involved in housing policy formulation by integrating slumsquatter structures as the problematique. The approach posits that the total need of urban housing and facilities should be approached from the components' side because of the differences in household characteristics i.e. (dependency ratios, income, education, and land teneurship. Linking variables into an estimating equation, we obtain the following.

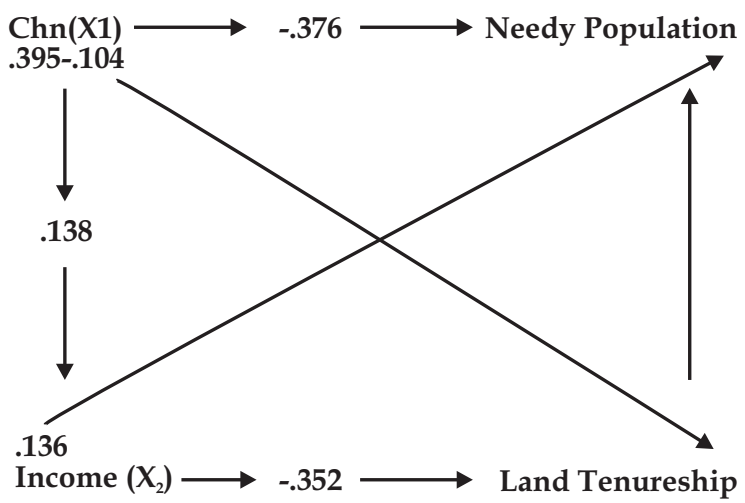


As such, the present study has attempted to focus analytically on the policy issue through the operationalization of the ClientOriented approach in relation to the goal of sustainable cities. Thus from the planological view point, slum-squatter eradication and sustainable development attainment implies dealing primarily with the needs of the urban poor. Therefore, the Client-Oriented model is to determine the target population by answering the questions: Who needs What, Where, and Why?

\section{Philosophical Perspective Advanced}

In building the attitude advanced here, we argue out that we ought to have the Power of the Will to Believe. According to William James (1911), the only way of mankind out of his problems is subjectivism because according to it, a small degree of a given act is good for it will lead to a better level of goodness. Such a perspective is only possible if we can regret against our own actions. In this context without regret, a determinist thinking of all that which are possible without comprehending clear facts about experience will pave way to pessimism which will lead him to believe that everything is really good.

This kind of optimism will bring along with it a greater degree of ignorance about ethics, or in other words, some kind of status that eventually leads to disaster. An example is seen in the various governmental policies on slum-squatter settlements expressed in form of massive destruction by authorities and widespread community protests. We cannot understand the will to act whatever the feelings upon it unless we believe that such an action is actually good or evil. We cannot tell that an action taken is bad unless we regret its occurrence.

In between the two extreme attitudes upon slum-squatter development of freedom and restraint to build, we advance a new or third attitude wherein, we argue that either those who violate the freedom and effort to choose or those who violate determinism are individuals laddered with wrong attitudes and extremity. The attitude upon slum squatter settlements is not, an issue of formal or informal; legal or illegal neither standard nor substandard. Here, the approach to slum - squatter development ought not to be that of either freedom or determinism but rather, that of both/and. This leads us to the process of housing consolidation proposed by Turner John and colleagues in the 1970's.

Although much has been talked about housing consolidation or self-help housing process, we see that the idea of self-help by Turner J lacks a philosophical attitude or background. The attitude advanced here is one that combines together determinism and freedom and continues to stress the impact of cause - effect element due to man's participation not only as a critique but also as a creator of his environment. Here we neither agree with the inter-deterministic view which does not observe that there are decisions made without adhering to the cause - factors and hence side up with freedom advocates; nor do we agree with determinism because of extremity and so does not side with freedom and so in itself has no sense of moral responsibility. The attitude towards slum - squatter settlements taken here is that of self-determinism wherein the SELF acts as the cause, centre of creativity, and has the freedom to choose.

From the biotic perspective, life is intended to uphold the maintenance of the organism as a whole and therefore housing policies should be directed to the attainment of this objective for SELF is a biotic organism on one hand. Our perception here is that mankind is a unity organism characterised with a sense of self-consciousness, ability of individual intuitiveness and response, being a centre of creativity, and also to certain limits the ability of self-formation influencing the behaviour of others and paving direction to new processes in the outside world. As such, it implies that man has freedom to choose that can be proved by his attempts to consolidate his shack. 


\section{CONCLUSIONS}

There are four major aspects of the housing problematique: affordability defined in terms of the ratio of housing costs to income; adequacy that includes quality and overcrowding; neighbourhood conditions; and availability in terms of supply. Adverseness of one or all of these housing aspects in any city conjures up images of low quality and overcrowded conditions that are principally the concern of low income or minority people.

It is clear that not all critical events are guaranteed to generate a high profile problem. What is important is to note that an event such as housing or education, etc. provokes a problematic situation when it:stimulates media attention,involves some arm of the government,demands governmental decision, is not written-off by the public as a freak, andrelates to personal interests of a significant number of the citizens.

By these criteria, education is a vital public issue that needs immediate attention basing in mind its inter-twinned relations with all aspects of human existence today. This can be achieved when the sponsoring agent and higher institutions of education become legitimate and authoritative sources of information as regards the impact of any policy that government intends to enact. Without this, it will be difficult because the national law has been overpowered by incompetent authorities but with economic power i.e. the law has been pocketed.

In this context, the question then is 'What should be done?' As far as this study is concerned, there are a number of answers to this question amongst others:Firstly, the Indonesian Ministry of Urban Development Planning, Human Settlement and Housing judged with the responsibility of governing and strategic planning seems to be lacking a disciplined effort to produce fundamental decisions and actions that shape and guide what an organisation is, what it does, and why it does it. This is because it ought to be noted that in the program, strategic planning is a "big picture", an approach that is concerned with identifying and responding to the most fundamental issues facing the community or an organisation. If the Indonesian government is to alleviate the problem of slumsquatter settlements, then it should embark on the NMP - Reform Wave hypothesis that more-orientation in the public sector will lead to greater cost-efficiency for governments. In short, instead of entrusting the construction and provision of low-income houses to private sectors, the government itself should take it as its own responsibility. But the question is "What is NMP Reform and how does it operate?" To achieve this, the Indonesian government as a whole, needs to set up a Public Service Commission (PSC). The Commission is a Human Resource Manager that "plans and carries out policies related to phases of personnel activities". Its role is Recruiting, Interviewing, Selecting, and Appointing [RISAP] employees to fill vacant positions on merit. Thereafter, it plans and conducts a 'new employee orientation' to foster a positive attitude towards organisational goals.

Secondly, housing consolidation or improvement by people themselves as an ethic identifies the logic of domination perpetuating the domination of the urban poor. Thus, this ethic of self-care should form the basis of policies on low-income housing for inherent within this ethic is the resident participatory aspects advocated. In this housing consolidation process, is bound not only the Care Ethic but also philosophical concepts such as diversity and unity central to the attainment of environmental sustainability.

Thirdly, in relation to the Self-Care Ethic Philosophy, Indonesia is losing her Self-Identity. From this perspective, Indonesia's philosophy has lost ground because of materialism. This can be proved by the fact that social relationships and the feeling of goodwill are being defined by materialistic thoughts. Authorities have no feeling of empathy towards the community; whereas the community 
have equated their kinship ties with money. Such a national character is dangerous for it will eventually end in disintegration. This has become so because as far as the National Philosophy of Pancasila is concerned, the government has abandoned the backbone of this philosophy that is Social Reformation and Leadership. As a result, the nation is losing her identity because of the nature of the system of administration applied and the structure of administration that is not clear.

Fourthly, an effort should be made to developing financial institutions for the poor. Subsidised formal financial housing has failed. But the question: "Is there scope for expanding informal finance, the most common source of finance for the poor?" or in another form, "How can the poor man's major source of credit enter into the National Urban Housing Development Policy?" remains something calling for research.

\section{REFERENCES}

Bertalaffyf (1948)General Systems Model. Oxford Univ. Press.

Cedric P (1996)The Changing Roles in Selfhelp Housing in Urban Policies, 1950-1996:Experiencein Developing Countries. London: Twp
De Soto (1989)The Concept of Expectative Property Right and Housing in Peru Global Report on Human Settlements. London: Oxford University Press.

Direktoral Jend. Cipta Karya (1979)Pedoman Perencanaan Lingkungan Permukiman. Bandung: Yayasan Lembaga Penyelidikan Masalah Bangunan.

Gene BR(1988)Site Planning: Environment, Process and Development. New Jersey: Prentice-Hall

Guiness (1986) Slum - Squatter development and Latin American Cities: Research Paper for Discussion. Sao Paulo, Brazil.

Matinguny AA(2004)Pilot Study Results on the Case Study Areas.Unpublished

Michael B (1978). The Urban Models in the Planning Process, Progress in Research and Applications, Vol.1. Editors DT.Herbert and RJ. Johnston. John Wiley and Sons, Toronto.

Setiawan B and Garr JD (1992) Urban Growth, Land and Housing Problems.Waterloo UniversitySmith DM (1977)Human Geography: A Welfare Approach. London:Erdward Arnold.

Turner FJ (1976)Urban Housing Strategies. London: Pitman Publishing co. 